\title{
NARRATIVE AS A TOOL OF SHAPING NEGATIVE IMAGE OF UKRAINE IN CONDITIONS OF HYBRID WARFARE
}

\section{Stanislav Hrechka ${ }^{1}$}

\section{DOI: https://doi.org/10.30525/978-9934-26-050-6-54}

For years, Ukrainian society has been the object of hostile information and psychological operations, propaganda, fakes, manipulations, and suggestions that distort perceptions of reality, disorder consciousness, influence behavior and decision-making, impose a specific agenda, and so on. These operations' strategic goal is the deconstruction and liquidation of Ukraine as a state by blurring the Ukrainian identity, fragmenting the nation and society, destabilizing the political system, delegitimizing public authorities, destroying public institutions, and so on. Discrediting Ukraine and undermining its image is one of the continental war tasks because the image is a strategic intangible capital of the state, which determines its geopolitical position, affects international partnership, the effectiveness of diplomacy, and foreign policy. Besides, the country's image is an essential factor in national security because it motivates internal political, economic, and social stability, legitimizes public authorities' activities, affects the rule of law, etc.

An image is a holistic stable representation of a specific object of reality, which arises as a result of perception and concomitant filtering of information from the external environment about this object through the prism of existing stereotypes and which exists and reproduces in the mass or individual consciousness [1].

In the conditions of information and psychological confrontation, strategic narratives became one of the most powerful tools (technologies) of influencing the image of Ukraine. A narrative is a form of human comprehension of the world around, registration of experience and ordering of meanings, a way of giving meaning to the sphere of social actions [2, p. 153]. The concept of «strategic narrative» is defined as a convincing storyline based on society's ideas and values, explains the events, and concludes them [3, p. 149]. States, corporations, public, political and social structures formulate their interests and values with strategic narratives. Dominant media use narratives for framing (integrating information into the context of a narrative for «correct» perception), priming (using targeted incentives to provoke a response in a specific audience), and setting an «agenda» (forming ideas about the importance of some and other events, facts, personalities, etc.)

\footnotetext{
${ }^{1}$ Taras Shevchenko National University of Kyiv, Ukraine
} 
in order to impose on society a set of norms and patterns of behavior [4, p. 30-31]. Constructed narratives begin to determine the behavior, a person begins to see in reality what the focus of the narrative is on and omits what the narrative does not describe [5].

Narrative methods of modeling the image of Ukraine are studied based on texts of Russian-language media socio-political discourse (online publications «LIFE» and «Politikus.ru»). We found a repertoire of narratives broadcast in order to influence the image of Ukraine. Among them are the following thematic groups of narratives: the Ukrainian state, the Ukrainian army, and the Ukrainian government.

After the Revolution of Dignity, Russian propaganda has focused on Ukraine, and one of its most important strategies was to form a negative image of Ukraine as a «failed state.» Consequently, a vast repertoire of strategic narratives was used to destabilize the country's situation, demoralize and disarrange Ukrainians' consciousness, discredit the government, deprive Ukraine of international support and legitimize the annexation of Crimea and the military invasion of eastern Ukraine. Let us look at some of them. 1) Ukraine is an artificially formed state construct in which social groups have different (incompatible) values, identity, and language. 2) Ukraine is a country under the West's external control, portrayed as an entirely dependent puppet state, with foreign curators' political decisions (USA, EU). 3) Western partners have stopped supporting Ukraine. This narrative complements the previous one and forms the image of a weak, dependent country deprived of international support. 4) The Ukrainian state is in an acute crisis. This narrative forms the image of a hopeless humanitarian and social crisis in Ukraine. 5) The Ukrainian economy is on the verge of collapse. The narrative creates an image of an inevitable future economic collapse that Ukraine will not stop on its own. 6) Ukraine is dependent on the International Monetary Fund. The IMF has consistently kept Ukraine's economy relatively stable, but this makes Ukraine politically dependent. 7) The Ukrainian economy cannot exist without trade and economic ties with the Russian Federation. This narrative conveys the idea that the Ukrainian economy cannot exist outside Russia's trade and economic orbit, and it is this attempt at separation has led to the crisis. At the same time, there is a strong message about the possibility of restoring stability if we choose the pro-Russian vector. 8) Foreign companies withdraw capital from Ukraine. The narrative deepens the theme of economic catastrophe, depicting an outflow of investment and capital that will only exacerbate the crisis. 9) Right-wing radicalism is flourishing in Ukraine, which the authorities and law enforcement agencies cannot control. 10) Ukraine is ruled by a dictatorship, an anti-democratic European country where the government restricts citizens' rights and freedoms. 11) Ongoing 
civil war in Ukraine. This narrative is key to Russian propaganda and diplomacy, which officially separates Russia from the military conflict and plans to avoid responsibility, evade sanctions, and freeze the conflict and gain effective mechanisms for geopolitical influence on Ukraine.

The narratives of this group interpret the past (explain the status of failedstate by historical conditioning), the present (the crisis in the country is called the consequences of the Revolution of Dignity), and the future (predict the collapse of the Ukrainian state, disintegration into separate territories that will be part of neighboring states). Some narratives broadcast the possibility of a successful alternative future for Ukraine - in political and economic integration with Russia.

During the hybrid war, a strategically crucial Russian propaganda task was to create a negative image of the Ukrainian army to dehumanize and demonize it in the local population's eyes and discredit it with the international community. The negative image of the army weakens its potential and power, demoralizes soldiers. Consider the strategic narratives in which these ideas were implemented. 1) Criminal actions of the Armed Forces of Ukraine in the East. Such narratives modeled the image of Ukrainian punitive occupiers who brought death to the peaceful lands of Donbas. 2) Atrocities of Ukrainian volunteer troops. This narrative forms the image of an uncontrolled, radical, criminal quasi-military, engaged in looting and mocking the civilian population. 3) The Armed Forces sabotage the work of the OSCE. Such a message makes it possible to portray Ukraine as an aggressor who kills its population, concealing facts from international observers. 4) The OSCE contributes to the destruction of Donbas' population by the Armed Forces of Ukraine. This narrative is a variant of the previous one. 5) Drugs are used in the Ukrainian army. That is how Russian propaganda «explains» the courage, steadfastness, and invincibility of Ukrainian soldiers. 6) Foreigners are fighting in eastern Ukraine. Such a narrative demonizes the Ukrainian army, which includes supposedly foreign troops to destroy the local population. 7) The Ukrainian army is weak and on the verge of collapse. This narrative forms the image of an inefficient, insolvent, outdated army whose military equipment and weapons are sold out. 8) The Ukrainian army is corrupt. This narrative adds to the previous image of the army an attribute of corruption, negligence. Narratives that discredit the Ukrainian army, for the most part, have no factual basis, are fakes - constructs of propaganda, the manipulative potential of which is being implemented through mass reproduction and multiple repetition.

The priority of information and psychological operations is, in particular, the creation of a negative image of public authorities, which depends on the international reputation, the effectiveness of diplomacy, domestic political 
stability, the legitimacy of power, etc. Consider the most typical strategic narratives. 1) The Ukrainian government is corrupt. Such a narrative discredits the Ukrainian government before the international community, complicates the foreign policy context, and increases socio-political tension and distrust of Ukrainians. 2) The Ukrainian government is unprofessional and inefficient. Such a government's activity only brings the moment of the state's collapse closer; it is impossible to negotiate and cooperate with it; it does not effectively use aid and maintain socio-political integrity; such a government will not bring the country out of the crisis. 3) Ukrainian authorities rob Ukrainians. The narrative complements the previous ones: the government cannot save the country, so it tries to plunder as much as possible while the state still exists. The image of power is attributed to unprecedented cynicism features because it robs its impoverished people. 4) The Ukrainian government is Russophobic. The state has an anti-democratic discriminatory policy. They replace their inefficiency with Russophobic slogans. 5) The Civil War is beneficial to the Ukrainian government. The narrative conveys the message that maintaining the state of war is an opportunity for the authorities to extend their term of office and plunder the state under this guise. Thus, strategic narratives form the image of an undemocratic, corrupt, ineffective government that plunders the country and artificially prolongs the war.

To sum up, the analysis of Russian-language socio-political media discourse showed that in the conditions of information and psychological confrontation, the modeling of Ukraine's image is done by deconstructing a positive image (state, army and government) and constructing a negative one. Such image transformations are realized through the systematic and consistent application of strategic narratives, which have a powerful explanatory, interpretive, and transformational potential. The image can be modeled using a holistic monolithic master narrative and sub-narratives that will function within the narrative, deepening and detailing it. Deformation of the existing image can be realized using a set of controversial sub-narratives to destroy the whole narrative and compete with it.

\section{References:}

1. Bozadzhiev V. L. (2015) Politicheskaya psikhologiya: uchebnoe posobie dlya studentov vysshikh uchebnykh zavedenij [Political Psychology: A Study Guide for Higher Education Students]. Moscow: Akademiya Estestvoznaniya. Retrieved from: https://monographies.ru/en/book/view?id=275 (accessed 15 February 2021).

2. Profatilova L. G. (2008) Narrativy kak mezhdiscziplinarnyj konstrukt [Narratives as an interdisciplinary construct]. Metodolohiia teoriia ta praktyka sotsiolohichnoho analizu suchasnoho suspilstva, vol. 14, pp. 153-156.

3. Barovska A. V. (2015) Stratehichni komunikatsii: dosvid NATO [Strategic communications: NATO's experience]. Stratehichni priorytety, no. 1, pp. 147-152. 
4. Ozhevan M. A. (2016) Hlobalna viina stratehichnykh naratyviv: vyklyky ta ryzyky dlia Ukrainy [The Global War of Strategic Narratives: challenges and risks for Ukraine]. Stratehichni priorytety, no. 4(41), pp. 30-40.

5. Autesserre S. Dangerous tales: dominant narratives on the Congo and their unintended consequences. Retrieved from: https://academic.oup.com/afraf/articleabstract/111/443/202/16975?redirectedFrom=PDF (accessed 15 February 2021). 